\title{
Determinan Tingkat Kemiskinan Kabupaten/Kota Di Provinsi Jawa Timur Tahun 2017-2019 Menggunakan Spatial Error Model dengan pendekatan Fixed Effect
}

\author{
(Determinants of District/City Poverty Levels in East Java Province in 2017-2019 Using Spatial \\ Error Model with Fixed Effect Approach)
}

\author{
Muhammad Rifqi Maulana Firdaus ${ }^{1 *}$, Siti Muchlisoh² \\ ${ }^{1,2}$ Politeknik Statistika STIS \\ E-mail: ${ }^{2}$ 211709862@stis.ac.id, ${ }^{2}$ sitim@stis.ac.id
}

\begin{abstract}
ABSTRAK
Pada tahun 2019 terjadi pengelompokan tingkat kemiskinan kabupaten/kota di Jawa Timur. Tingkat kemiskinan yang tinggi berada di wilayah utara, sementara wilayah bagian tengah hingga bagian selatan Jawa Timur sudah memiliki tingkat kemiskinan yang tergolong rendah. Hal ini mengindikasikan tingkat kemiskinan kabupaten/kota di Jawa Timur memiliki keterkaitan spasial antarwilayah. Pola keterkaitan spasial ini juga terlihat di tahun 2017 dan 2018. Maka dari itu, penelitian ini bertujuan mengidentifikasi keterkaitan spasial tingkat kemiskinan kabupetan/kota di Jawa Timur dan variabel-variabel yang memengaruhi tingkat kemiskinan tersebut dari tahun 2017 sampai 2019. Model yang diterapkan adalah SEM dengan pendekatan FEM. Penelitian ini mencakup seluruh wilayah di Jawa Timur. Variabel dependen dari penelitian ini merupakan tingkat kemiskinan. Variabel yang diduga memengaruhi tingkat kemiskinan adalah pertumbuhan ekonomi, IPM, dan jumlah penduduk. Data keseluruhan variabel dikutip dari BPS. Periode penelitian ini dari tahun 2017 sampai 2019. Periode penelitian ini dipilih dengan pertimbangan ketersediaan data untuk berbagai variabel yang diperlukan. Dari model terbaik diperoleh pertumbuhan ekonomi, IPM, dan jumlah penduduk berpengaruh signifikan dalam penurunan tingkat kemiskinab. Selain faktor tersebut ada faktor lain yang dapat memengaruhi tingkat kemiskinan yang berada pada wilayah yang dianggap bertetanggaan.
\end{abstract}

Kata kunci: kemiskinan, SEM, FEM

\begin{abstract}
In 2019 there was a clustering of district/city poverty levels in East Java. The high poverty rate is in the northern region, while the central to southern part of East Java already has a low poverty rate. This indicates that the poverty level of districts/cities in East Java has a spatial relationship between regions. This pattern of spatial linkage was also seen in 2017 and 2018. Therefore, this study aims to identify the spatial linkage of the district/city poverty level in East Java and the variables that affect the poverty level from 2017 to 2019. The model applied is SEM. with the FEM approach. This research covers all areas in East Java. The dependent variable of this study is the level of poverty. The variables that are thought to influence the poverty rate are economic growth, HDI, and population. Data on all variables are quoted from BPS. The period of this research is from 2017 to 2019. This research period was chosen by considering the availability of data for the various variables needed. From the best model, it is found that economic growth, HDI, and population have a significant effect on reducing poverty levels. In addition to these factors, there are other factors that can affect the level of poverty in areas that are considered neighbors.
\end{abstract}

Keywords: poverty, SEM, FEM

\section{PENDAHULUAN}

Kemiskinan adalah fenomena yang hampir terjadi semua di dunia. Kemiskinan dapat diartikan suatu taraf kesejahteraan hidup yang rendah, yaitu terdapat kekurangan materi yang terjadi pada beberapa orang dibandingkan dengan taraf kesejahteraan hidup yang berlaku dalam masyarakat umum. Rendahnya taraf kesejahteraan hidup sangat erat kaitannya dengan sistem perekonomian suatu wilayah, dan dapat memengaruhi sistem perekonomian wilayah sekitarnya (Simatupang, 2003).

Teori trickle down effect menjabarkan perubahan yang dilakukan beberapa orang secara otomatis dapat mengalir secara vertikal, menciptakan bermacam-macam peluang ekonomi, sehingga menciptakan berbagai kondisi untuk menciptakan pemerataan pertumbuhan ekonomi. Teori ini menyiratkan bahwa pertumbuhan ekonomi akan disertai aliran ke bawah otomatis dari penduduk yang bercukupan menuju penduduk yang bergantungan pada hidup. Oleh karena itu, dampak pertumbuhan ekonomi terhadap pengentasan kemiskinan adalah dampak jangka panjang dari aliran ke bawah dari penduduk yang bercukupan menuju penduduk yang bergantungan pada hidup. Sehingga jika orang miskin hanya menerima sebagian kecil dari seluruh keuntungan 
yang dihasilkan oleh pertumbuhan ekonomi, maka penurunan tingkat kemiskinan tidak signfikan. Karena pertumbuhan ekonomi berpihak pada yang kaya daripada yang miskin, dan ketimpangan pendapatan meningkat, situasi ini dapat menciptakan peluang untuk meningkatkan kemiskinan.

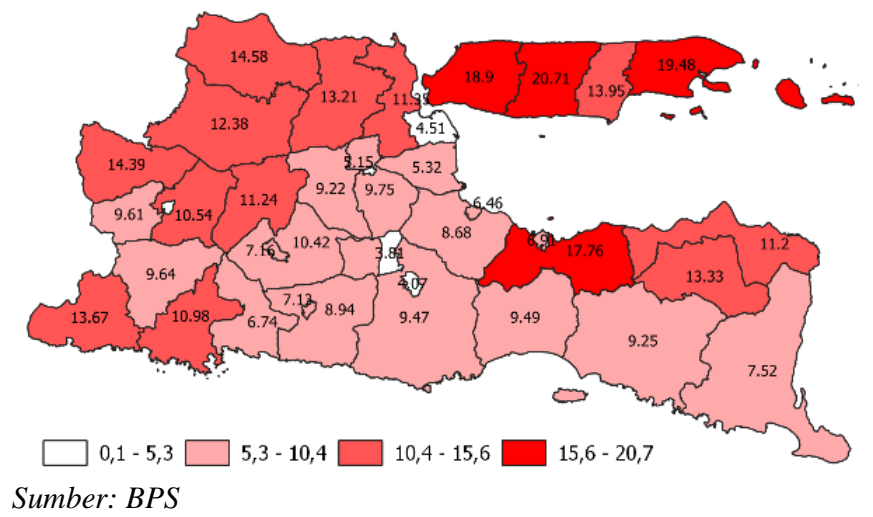

Gambar 1. Tingkat kemiskinan kabupaten/kota di Jawa Timur tahun 2019

Pada Gambar 1 diketahui bahwa tingkat kemiskinan kabupaten/kota di Jawa Timur tahun 2019 terjadi pengelompokan di wilayah utara Jawa Timur seperti Kabupaten Lamongan, Kabupaten Gresik, dan daerah Pulau Madura. Sementara wilayah bagian tengah Jawa Timur hingga bagian selatan sudah memiliki tingkat kemiskinan yang tergolong rendah, hanya beberapa wilayah saja yang angka tingkat kemiskinannya tinggi. Maka tingkat kemiskinan kabupaten/kota di Jawa Timur dipengaruhi oleh kemiskinan di wilayah sekitarnya. Hal ini mengindikasikan tingkat kemiskinan kabupaten/kota di Jawa Timur memiliki keterkaitan spasial antarwilayah. Pola keterkaitan spasial ini juga terlihat pada tahun 2017 dan 2018. Hal ini sesuai dengan hukum geografi yang dikemukakan oleh Tobler yang menyatakan bahwa "everything is related to everything others, but things near is more related than things far away". Semuanya terkait satu sama lain, tetapi hal-hal yang lebih dekat memiliki pengaruh yang lebih besar. Hukum Tobler digunakan sebagai tulang punggung penelitian analisis data spasial. Dalam data spasial, penelitian di suatu wilayah dapat dipengaruhi oleh wilayah lain yang berdekatan (Schabenberger, 2005).

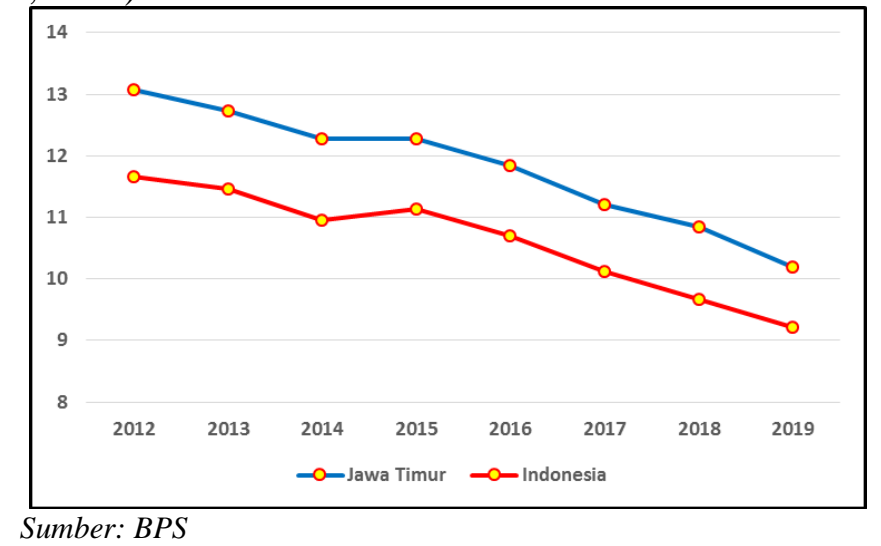

Gambar 2. Tingkat kemiskinan Indonesia dan Jawa Timur 2012-2019

Dari Gambar 2 diketahui bahwa adanya trend off tingkat kemiskinan Jawa Timur dari tahun 2012 sampai 2019. Pada tahun 2012 tingkat kemiskinan Jawa Timur sebesar 13,08 persen sedangkan pada tahun 2019 sebesar 10,20 persen. Hal tersebut menunjukkan bahwa pemerintah daerah Jawa Timur berhasil menjalankan beberapa program dengan baik yang dapat menekan angka persentase penduduk miskin Provinsi Jawa Timur. Sementara jika dilihat nilai pertumbuhan ekonomi Jawa Timur cenderung berada pada angka 5 persen.

Tingkat kemiskinan Jawa Timur mengalami penurunan dari tahun 2012 sampai 2019 namun posisi angka tersebut di atas nilai nasional. Secara umum tingkat kemiskinan Jawa Timur selama tahun 2012 hingga tahun 2019 berada pada urutan nomer 2 tertinggi di pulau Jawa. Oleh karena itu perlu diketahui faktor penyebab yang membuat Jawa Timur masih memiliki tingkat kemiskinan yang tinggi. Sehingga dibutuhkan penelitian lanjutan yang membahas faktor-faktor yang dapat memengaruhi tingkat kemiskinan di seluruh wilayah di Jawa Timur supaya diperoleh faktor-faktor yang berpengaruh signifikan dan dapat ditingkatkan untuk mengentas kemiskinan. Adapun permodelan regresi yang sesuai pada penelitian ini adalah Spatial Error Model (SEM) dengan pendekatan fixed effect. Adanya keterkaitan spasial yang terletak pada error sesuai dengan penelitian Rohmah (2017) yang menggunakan model spatial error untuk menganalisis pengaruh infrastruktur terhadap tingkat kemiskinan. Adapun penelitian lain yang dilakukan oleh Laswinia (2016) mengungkapkan bahwa 
terdapat pengaruh spasial yang terletak pada error dalam relasi antara persentase penduduk miskin dengan faktor lingkungan, ekonomi, dan sosial.

\section{METODE}

\section{Spatial Error Model dengan pendekatan Fixed Effect}

Model yang digunakan pada penelitian ini adalah Spatial Error Model (SEM) dengan pendekatan fixed effect. SEM menjelaskan bahwa variabel dependen bergantung pada satu set karakteristik lokal yang diamati dan komponen eror berkorelasi antarwilayah. Penggunaan metode SEM untuk menjelaskan dependensi spasial yang terjadi dalam model pada variabel independen lain yang belum termuat. SEM dengan fixed effect pada periode $t$ tertentu untuk observasi cross section sebanyak $N$ dinyatakan pada persamaan (1) dan (2) seperti berikut (Elhorst, 2009):

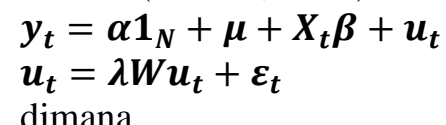

dimana,

$y_{t}=$ vektor variabel dependen pada periode $t$, berukuran $N \times 1$

$\alpha=$ parameter intersep

$1_{N}=$ vektor dengan setiap elemen bernilai 1 , berukuran $N \times 1$

$\mu=$ vektor parameter fixed effect, berukuran $N \times 1$

$X_{t}=$ matriks variabel independen pada periode $t$, berukuran $N \times K$

$\beta=$ vektor parameter koefisien regresi, berukuran $K \times 1$

$\boldsymbol{u}_{\boldsymbol{t}}=$ vektor autokorelasi spatial error, berukuran $\boldsymbol{N} \times \mathbf{1}$ dengan $\boldsymbol{u}_{\boldsymbol{i t}} \sim \boldsymbol{N}\left(\mathbf{0}, \sigma_{u}^{2}\right)$

$\lambda=$ koefisien parameter autokorelasi spasial

$W=$ matriks penimbang spasial, berukuran $N \times N$

$\varepsilon_{t}=$ vektor error pada periode $t$, berukuran $\boldsymbol{N} \times \mathbf{1}$ dengan $\varepsilon_{i t} \sim N\left(\mathbf{0}, \sigma^{2}\right)$

\section{Matriks Penimbang Spasial}

Matriks penimbang spasial (W) adalah matriks yang menjelaskan relasi antarwilayah dan diperoleh berdasarkan koordinat jarak atau kontiguitas. Dimensi matriks penimbang spasial $N \times N$, dimana $\mathrm{N}$ adalah banyaknya unit observasi. Pada penelitian ini, matriks penimbang spasial disusun berdasarkan koordinat wilayah dengan menggunakan metode $k$ nearest neighbours sebagai tetangga wilayah. K-nearest neighbors yaitu mendefinisikan wilayah tetangga sebanyak $k$ wilayah tetangga yang mempunyai jarak terdekat dengan wilayah yang diamati dimana tiap-tiap tetangga memiliki penimbang yang sama. Secara matematis, hal itu dapat dinotasikan $d_{i j}<d_{i j}(k)$ dimana $d_{i j}$ adalah jarak antara wilayah $i$ dan $j$ sedangkan $d_{i j}(k)$ adalah jarak antara wilayah $i$ dan $j$ pada urutan ke- $k$. Elemen matriks $w_{i j}=1$ jika wilayah $i$ dan $j$ dikatakan bertetangga, dan $w_{i j}=0$ untuk lainnya. Adapun kemudian jarak dihitung dengan menggunakan fungsi jarak Euclidean sebagai berikut:

$d_{i j}=\sqrt{\sum_{i=1}^{N}\left(g_{i}-h_{i}\right)^{2}} ; i=1,2, \ldots, N$

dimana titik pusat wilayah $i$ adalah $g_{1}, g_{2}, \ldots, g_{N}$ dan titik pusat wilayah $j$ adalah $h_{1}, h_{2}, \ldots, h_{N}$.

\section{Data dan Variabel Penelitian}

Penelitian ini mencakup seluruh wilayah di Jawa Timur. Variabel dependen dari penelitian ini merupakan tingkat kemiskinan. Variabel yang diduga memengaruhi tingkat kemiskinan adalah pertumbuhan ekonomi, IPM, dan jumlah penduduk. Data keseluruhan variabel dikutip dari BPS. Periode penelitian ini dari tahun 2017 sampai 2019. Periode penelitian ini dipilih dengan pertimbangan ketersediaan data untuk berbagai variabel yang diperlukan. 


\section{HASIL DAN PEMBAHASAN}

\section{Gambaran Tingkat Kemiskinan Jawa Timur}

Jika dilihat menurut kabupaten/kota, pada tahun 2017 sampai dengan tahun 2019 sebagian besar wilayah pada bagian utara Jawa Timur mempunyai tingkat kemiskinan yang tinggi termasuk Pulau Madura. Sebaliknya, sebagian besar wilayah-wilayah yang berada pada bagian tengah hingga selatan Jawa Timur memiliki tingkat kemiskinan yang rendah. Secara nasional, Jawa Timur satu di antara beberapa provinsi yang mempunyai ketersediaan pangan yang minim sehingga sektor pertanian adalah kegiatan ekonomi yang sangat berpengaruh dalam perekonomian Jawa Timur. Wilayah yang memiliki tingkat kemiskinan yang tinggi merupakan wilayah-wilayah yang sangat bertumpu pada sektor pertanian. Sementara wilayah yang memiliki tingkat kemiskinan yang rendah sudah mulai mengembangkan kegiatan ekonomi di bidang hotel, restoran, dan industri pengolahan. Tingkat kemiskinan kabupaten/kota di Jawa Timur tahun 2017-2019 disajikan pada Gambar 3.

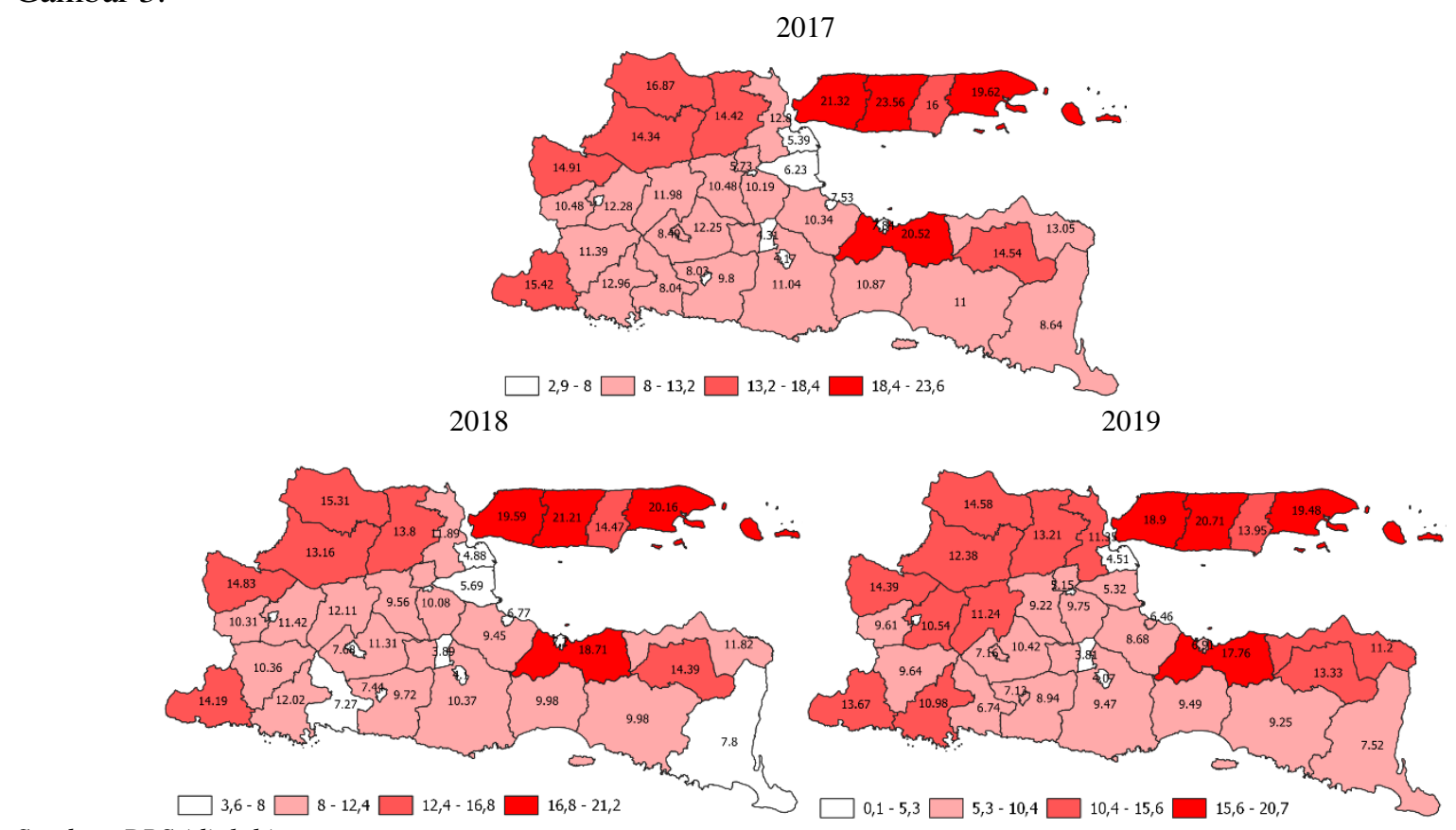

Sumber: BPS (diolah)

Gambar 3. Tingkat kemiskinan kabupaten/kota di Jawa Timur tahun 2017-2019

\section{Keterkaitan Spasial}

Identifikasi adanya keterkaitan spasial dilakukan dengan statistik Moran I. Statistik ini mengukur korelasi suatu variabel, yakni persentase kemiskinan antarwilayah. Statistik Moran I pada variabel persentase kemiskinan ditampilkan dalam tabel berikut.

Tabel 1. Statistik moran I.

\begin{tabular}{ccc}
\hline Tahun & I & p-value \\
\hline$(1)$ & $(2)$ & $(3)$ \\
2017 & 0,263 & 0,013 \\
2018 & 0,240 & 0,023 \\
2019 & 0,254 & 0,016 \\
\hline
\end{tabular}

Nilai Moran I persentase penduduk miskin tahun 2017 sampai dengan tahun 2019 seperti ditunjukkan pada Tabel 1 yang signifikan pada $\alpha=5$ persen. Hal ini menunjukkan bahwa adanya dependensi spasial antarwilayah, yang berarti tingkat kemiskinan di suatu wilayah dipengaruhi oleh faktor internal wilayah itu sendiri, juga dipengaruhi oleh tingkat kemiskinan wilayah-wilayah lain di sekitarnya.

Nilai moran I yang positif menyatakan adanya autokorelasi positif selama tahun 2017 sampai dengan tahun 2019, artinya terjadi pengelompokan wilayah berdasarkan tingkat kemiskinannya. Wilayah-wilayah yang mempunyai persentase kemiskinan rendah cenderung mempunyai wilayah-wilayah tetangga dengan persentase kemiskinan yang rendah pula. Begitu pula sebaliknya, wilayah-wilayah yang memiliki persentase 
kemiskinan tinggi cenderung mempunyai wilayah-wilayah tetangga dengan persentase kemiskinan yang tinggi pula.

\section{Model Tingkat Kemiskinan Jawa Timur}

Model regresi data panel spasial menggambarkan hubungan variabel independen terhadap variabel dependen pada setiap amatan, serta keterkaitan yang terjadi antarwilayah. Model spatial error (SEM) dengan pendekatan fixed effect yang diperoleh ditampilkan dalam Tabel 2 berikut.

Tabel 2. Model spatial error model dengan pendekatan fixed effect tahun 2017-2019.

\begin{tabular}{ccccc}
\hline Variabel & Koefisien & Std Error & t-stat & p-value \\
\hline Intercep & 57,873 & 8,073 & 7,168 & $0,000 *$ \\
LnPertumbuhan Ekonomi & $-0,034$ & 0,007 & $-4,768$ & $0,000 *$ \\
LnIPM & $-4,976$ & 0,455 & $-10,948$ & $0,000 *$ \\
LnJumlah Penduduk & $-2,522$ & 0,697 & $-3,618$ & $0,000 *$ \\
Spatial Error & 0,239 & 0,110 & 2,179 & $0,029 *$ \\
$R$-square & & 0,998 & \\
\hline
\end{tabular}

*) signifikan pada $\alpha=5$ persen

Dari model yang diperoleh pada Tabel 2, dengan tingkat signifikansi $\alpha=5$ persen bahwa seluruh variabel independen berpengaruh signifikan terhadap penurunan tingkat kemiskinan kabupaten/kota di Jawa Timur. Spatial error juga signifkan pada tingkat signifikansi $\alpha=5$ persen. Persamaan di atas menghasilkan $R$-square sebesar 0,998 yang berarti bahwa variabel independen yang terdapat dalam model penelitian mampu menjabarkan variasi tingkat kemiskinan sebanyak 99,8 persen sedangkan sisanya sebesar 0,2 persen dijabarkan oleh variabel independen lain yang berada di luar model penelitian. Nilai konstanta sebesar 57,873 menunjukkan nilai tingkat kemiskinan sebesar 57,873 persen ketika tidak ada pengaruh dari variabel apapun.

Nilai koefisien spatial error yang signifikan menjelaskan adanya keterkaitan spasial antarwilayah, yang berarti tingkat kemiskinan suatu wilayah terdapat dependensi spasial oleh variabel lain di luar model yang berasal dari wilayah-wilayah lain di sekitarnya. Nilai koefisien spatial error yang positif sebesar 0,239 menyatakan bahwa setiap kenaikan error (variabel lain yang berada di luar model) sebesar satu persen di wilayah tetangga dapat meningkatkan tingkat kemiskinan sebesar 0,239 persen di suatu wilayah. Dalam penelitian ini semua tetangga memiliki faktor yang sama dalam menurunkan tingkat kemiskinan di suatu wilayah.

Pertumbuhan ekonomi berpengaruh signifikan terhadap penurunan tingkat kemiskinan. Tabel menunjukkan nilai p-value variabel pertumbuhan ekonomi sebesar 0 (nol) dimana nilai tersebut kurang dari $\alpha$ $=5$ persen. Artinya, pada tingkat signifikansi $\alpha=5$ persen cukup bukti untuk menjelaskan variabel pertumbuhan ekonomi berpengaruh signifikan terhadap penurunan tingkat kemiskinan kabupaten/kota di Jawa Timur. Nilai koefisien yang negatif yaitu $-0,034$ menunjukkan peningkatan pertumbuhan ekonomi sebanyak satu persen dapat menurunkan tingkat kemiskinan sebanyak 0,034 persen, dengan anggapan variabel independen lain konstan.

IPM berpengaruh signifikan terhadap tingkat kemiskinan. Tabel menunjukkan nilai $p$-value variabel IPM sebesar 0 (nol) dimana nilai tersebut kurang dari $\alpha=5$ persen. Artinya, pada tingkat signifikansi $\alpha=5$ persen cukup bukti untuk menjelaskan variabel IPM berpengaruh signifikan terhadap penurunan tingkat kemiskinan kabupaten/kota di Jawa Timur. Nilai koefisien yang negatif yaitu $-4,976$ menunjukkan bahwa peningkatan IPM sebanyak satu persen, maka tingkat kemiskinan mengalami penurunan sebanyak 4,976 persen, dengan anggapan variabel independen lain konstan.

Jumlah penduduk berpengaruh signifikan terhadap tingkat. Tabel menunjukkan nilai p-value variabel jumlah penduduk sebesar 0 (nol) dimana nilai tersebut kurang dari $\alpha=5$ persen. Artinya, pada tingkat signifikansi $\alpha=5$ persen cukup bukti untuk menjelaskan variabel jumlah penduduk berpengaruh signifikan terhadap penurunan tingkat kemiskinan kabupaten/kota di Jawa Timur. Nilai koefisien yang negatif yaitu 2,522 menunjukkan bahwa peningkatan jumlah penduduk sebanyak satu persen, maka tingkat kemiskinan mengalami penurunan sebanyak 2,522 persen, dengan anggapan variabel independen lain konstan. 


\section{KESIMPULAN}

Mengacu pada hasil dan pembahasan, terdapat beberapa poin penting yaitu selama periode tahun 2017 sampai dengan tahun 2019, tingkat kemiskinan di Jawa Timur cenderung mengalami penurunan dan terdapat pengelompokan di bagian utara Jawa Timur. Seluruh variabel independen memiliki pengaruh yang signifikan terhadap penurunan tingkat kemiskinan. Selain faktor tersebut ada faktor lain yang dapat mengubah nilai tingkat kemiskinan kabupaten/kota di Jawa Timur yang berada pada wilayah yang dianggap bertetanggaan.

\section{DAFTAR PUSTAKA}

Anselin, Luc (1988) Spatial Econometrics: Methods and Models. Springer: Science+Business Media Dordrecht

Badan Pusat Statistik Provinsi Jawa Timur. (2018). Provinsi Jawa Timur Dalam Angka 2017. Surabaya: BPS. Badan Pusat Statistik Provinsi Jawa Timur. (2019). Provinsi Jawa Timur Dalam Angka 2018. Surabaya: BPS. Badan Pusat Statistik Provinsi Jawa Timur. (2019). Indeks Pembangunan Manusia Provinsi Jawa Timur 2019. Surabaya: BPS.

Badan Pusat Statistik Provinsi Jawa Timur. (2020). Provinsi Jawa Timur Dalam Angka 2019. Surabaya: BPS.

Badan Pusat Statistik Jawa Timur. Proyeksi Penduduk Pertengahan Tahun Menurut Kabupaten/Kota (Jiwa), 2015-2020. Diakses pada 20 Maret 2021 melalui https://jatim.bps.go.id/indicator/12/121/1/proyeksipenduduk-pertengahan-tahun-menurut-kabupaten-kota.html.

Badan Pusat Statistik Jawa Timur. IPM, 2015-2020. Diakses pada 20 Maret 2021 melalui https://jatim.bps.go.id/indicator/26/36/1/ipm.html.

Baltagi, B. H. (2005). Econometrics Analysis Data Panel: Third Edition. England: John Wiley dan Sons, Ltd.

Elhorst J. P. (2009). Spatial Panel Data Models. In Fischer MM, Getis A (Eds.) Handbook of Applied Spatial Analysis, Ch. C.2. Berlin Heidelberg New York: Springer.

Gujarati, D. N. (2004). Basic Econometric: Fourth Edition. New York: The Mac Graw Hill Companies.

Laswinia, V. D. (2016). Analisis Pola Hubungan Persentase Penduduk Miskin Dengan Faktor Lingkungan, Ekonomi, Dan Sosial Di Indonesia Menggunakan Regresi Spasial.

Rohmah, Dwi Maria. (2017). Analisis Pengaruh Infrastruktur Terhadap Tingkat Kemiskinan Di Kawasan Timur Indonesia (Penerapan Regresi Data Panel Spasial [Skripsi]. Jakarta: Politeknik Statistika STIS.

Schabenberger, O. and Gotway, C.A. (2005) Statistical Methods for Spatial Data Analysis. Chapman \& Hall/CRC, Boca Raton, FL.

Simatupang, P. (2003). Produksi Domestik Bruto, Harga dan Kemiskinan: Hipotesis “Trickle Down” Dikaji Ulang. Economics and Finance in Indonesia, 51(3), 291-324. 